\title{
A study on the electrolyte circulation effect of Mg-air battery
}

\author{
Jongwoo Park ${ }^{1,2}$, Kwangyeop Jang ${ }^{4}$, Sangwon Seo ${ }^{1,2}$, Jaehyo Park ${ }^{1,2}$, Wansung Kwon ${ }^{1,2}$, and Dongjin Kim ${ }^{1,2,3 *}$ \\ ${ }^{1}$ SUNKWANG L.T.I. INC., Central Research Institute of Technology, Seoul, Republic of Korea \\ ${ }^{2}$ SUNKWANG L.T.I. INC., Institute of Field Research Center, Seoul, Republic of Korea \\ ${ }^{3}$ SUNKWANG L.T.I. INC., Head-Quarter, Seoul, Republic of Korea \\ ${ }^{4}$ Korea Conformity Laboratories, Parts and Materials Headquarters, Seoul, Republic of Korea
}

\begin{abstract}
The theoretical discharge energy density of the Mg-Air battery, which is attracting attention as a next-generation battery, was modelled and the efficiency of electrolyte circulation was compared. After that, $180 \mathrm{kWh}$ class power facility was built using Mg-Air batteries, and the effect of electrolyte removal according to the circulation method was compared and investigated.
\end{abstract}

\section{Introduction}

Recently, the need for high-capacity batteries has emerged due to the rapid growth of the micro and smart grid technologies. Lithium ion batteries with the highest energy density are used in the ESS of most renewable energy power plants currently being built. However, currently used Lithium ion batteries are approaching technological limits, and the development of batteries with higher energy density is required.

For this reason, research on Metal-Air batteries having a higher theoretical energy density than Lithium ion batteries has been actively conducted in recent years. The metal-air battery is a new concept fuel cell that sues metal as an anode and air as an anode, and has very high potential energy. In addition, unlike other fuel cells, it is known as an economical and eco-friendly clean energy source, as it does not use precious metal catalyst and uses an inexpensive electrolyte as a medium. [1]

The performance of the Metal-Air battery is greatly affected by the energy density of reaction characteristics of between Metal to Air. Therefore, metal materials are used in consideration of the correlation between the type of metal and electrolyte. In particular, when $\mathrm{NaCl}$ electrolyte is used, it has been reported to exhibit the best output characteristics in $\mathrm{Mg}$ metal, and it is very safe in terms of use because there is on generation of harmful substances and is chemically stable. [2-5]

Therefore, if the Mg-Air battery is used as a distributed power source of the micro gird itself for as an emergency power source such as a UPS facility for uninterrupted operation, its value is expected to increase further in terms of lifespan and maintenance.

As Mg-Air battery is that generates power by using the oxidation reaction of $\mathrm{Mg}$, the efficiency of the battery is determined by how stable the metal oxidation reaction can generate power for a long period of time response to the load. In particular, it is expected that there will be many differences in battery efficiency depending on the continuous supply of $\mathrm{H}_{2} \mathrm{O}$ inside the electrolyte, which disappears due to chemical reactions during the power generation process of the $\mathrm{Mg}$-Air battery, and the eliminate method for $\mathrm{Mg}(\mathrm{OH})_{2}$ by-products.

Until now, most of the research on Mg-Air batteries has focused on the type of metal anode, electrolyte concentration, and characteristics of the air cathode. [6] However, despite the fact that the efficiency of the metalfuel cell is determined by the continuity of the oxidation reaction, the research on the continuous operation method of the Mg-Air battery remains at an almost incomplete level.

Therefore, in this study, the theoretical potential energy amount for a magnesium-air battery using $\mathrm{NaCl}$ electrolyte was modelled, and the efficiency characteristics of the battery were examined through discharge according to the operating method.

\section{Operating efficiency of Mg-Air battery}

\subsection{Energy density modelling of Mg-Air battery}

Figure 1 is a Unit Cell of the Mg-Air battery Used in this study. This battery is a chemical battery that generates electromotive force through the oxidation of the $\mathrm{Mg}$ anode and reduction of Air cathode.

In the Standard state, the complete reaction equation combining the oxidation of $\mathrm{Mg}$ anode and reduction of Air cathode is shown in equation (1)

$$
2 \mathrm{Mg}+\mathrm{O} 2+2 \mathrm{H} 2 \mathrm{O} \rightarrow 2 \mathrm{Mg}(\mathrm{OH}) 2
$$

\footnotetext{
a Corresponding author: djkim@i-sk.com
} 


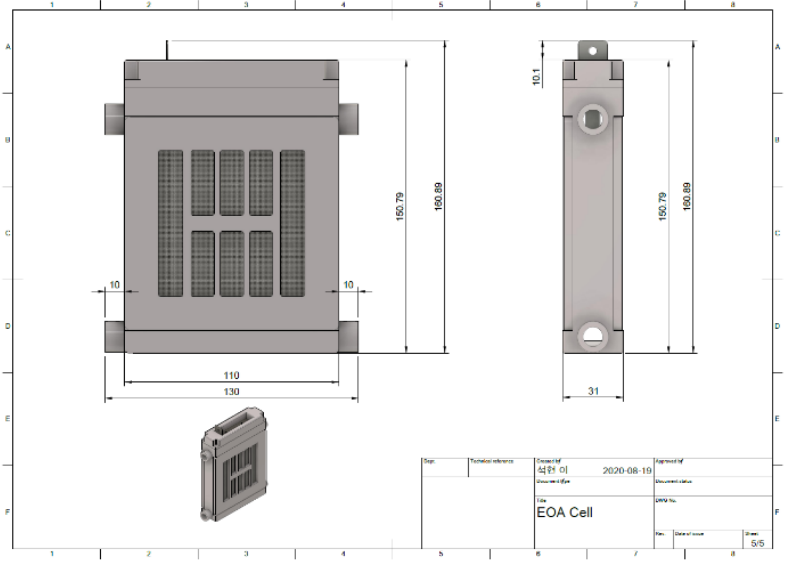

Figure 1. Configuration of the Mg-Air battery unit cell

The modelling of the discharge energy density generated through the oxidation process of the $\mathrm{Mg}$ anode is made through equations (2) and (3).

$$
\begin{aligned}
& \frac{\mathrm{kg}}{\mathrm{g} / \mathrm{mol}} \times \frac{\mathrm{A}}{\mathrm{mol} \cdot \mathrm{sec}} \times \frac{\mathrm{hr}}{\mathrm{sec}} \times V=k W h \\
= & \frac{\mathrm{kg}}{\text { atomic weight of Metal anode }} \times C \times \frac{\mathrm{hr}}{\mathrm{sec}} \times V
\end{aligned}
$$

When $\mathrm{Mg}$ anode is applied to the corresponding discharge energy density model, the theoretical discharge density of the final $\mathrm{Mg}$ anode is as shown in equation (4). That is, when all $1 \mathrm{~kg}$ of $\mathrm{Mg}$ anode is oxidized, it can be expected that $2.2 \mathrm{kWh}$ of power can be obtained.

$$
\frac{1 \mathrm{~kg} \times 2}{24.3} \times 96,500 \mathrm{C} \times \frac{1 \mathrm{hr}}{3600 \mathrm{sec}} \times 1.2 \mathrm{~V} \cong 2.2 \mathrm{kWh}
$$

However, as can be seen from the complete reaction equation in equation (1), $\mathrm{H} 2 \mathrm{O}$ inside the electrolyte is used during the power generation process, reducing the total amount of electrolyte.

In addition, due to the $\mathrm{Mg}(\mathrm{OH}) 2$ by-product generated, the volume that the electrolyte can enter into the Mg-Air battery decreases, and the active surface area of the $\mathrm{Mg}$ anode and the $\mathrm{NaCl}$ electrolyte in contact decrease. Therefore, the amount of electricity produced when $1 \mathrm{~kg}$ of $\mathrm{Mg}$ is actually discharged is less than $2.2 \mathrm{kWh}$.

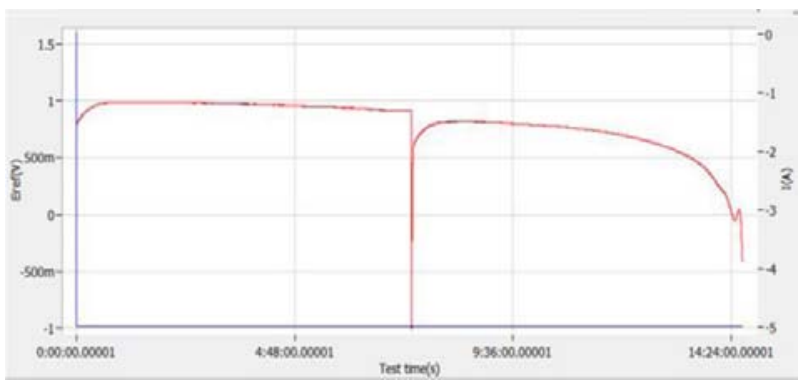

Figure 2. Discharge curve of non-circulating Mg-Air battery

Figure 2 shows the output of unit Mg-Air battery without circulating the electrolyte by discharging it until all of the $\mathrm{Mg}$ anode are consumed, and the result is as shown in equation (5).

$$
\begin{aligned}
& \text { Non circulating Mg - Air Battery Unit Cell } \eta \\
= & \frac{1.606 \mathrm{kWh}(\text { Experimantal energy quantity) }}{2.2 \mathrm{kWh} \text { (Theoretical energy quantity })}=0.73
\end{aligned}
$$

Figure 3 shows the output of unit Mg-Air battery with circulating the electrolyte by discharging it until all of the $\mathrm{Mg}$ anode are consumed, and the result is as shown in equation (6).

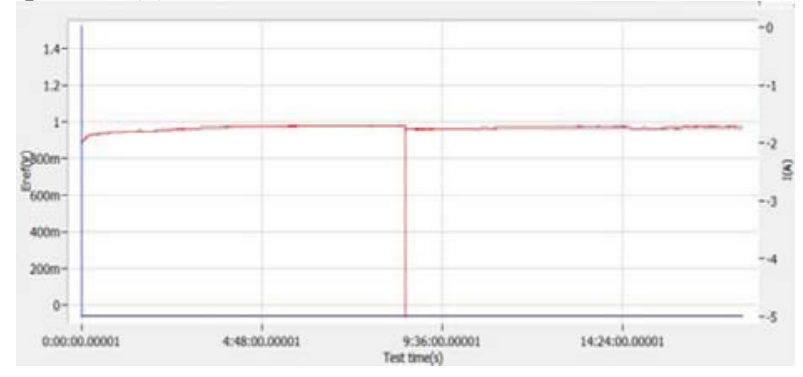

Figure 3. Discharge curve of circulating Mg-Air battery

$$
\begin{gathered}
\text { Circulating } \mathrm{Mg}-\text { Air Battery Unit Cell } \eta \\
=\frac{2.002 \mathrm{kWh}(\text { Experimantal energy quantity })}{2.2 \mathrm{kWh}(\text { Theoretica energy quantity })}=0.91
\end{gathered}
$$

\subsection{Experiment of circulation efficiency}

Therefore, a large-capacity power facility is built through the serial and parallel connection of $\mathrm{Mg}$-Air batteries, and actually use it as a distributed or emergency power, it can be seen that continuous supply of electrolyte and removal of generated by-product are essential.

In order to confirm the effect of removing by-products according to the circulation method, $180 \mathrm{kWh}$ class largecapacity power facility was actually built through serial and parallel connection of Mg-Air battery.

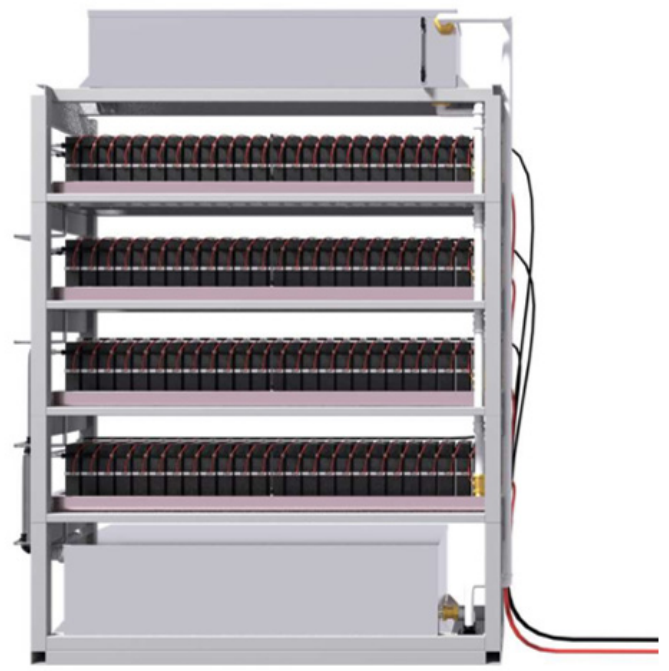

Figure 4. Configuration of the Mg-Air battery Rack (25S-4P)

Figure 4 shows the structure of the constructed $\mathrm{Mg}$ Air battery Rack. Each layer has $25 \mathrm{Mg}$-Air batteries connected in series, and each layer is connected in parallel to form a total structure of $25 \mathrm{~S}-4 \mathrm{P}$. 
When the electrolyte stored in the lower tank rises to the upper tank by driving the circulation pump, the electrolyte flows down the pipe by gravity and is fed into each Mg-Air cell. The Mg-Air battery is equipped with and outlet for adjusting the electrolyte level, and when the injected electrolyte exceeds the corresponding level, it is discharged through the fitting and collected again the lower tank.

Figure 5 shows the movement of the electrolyte inside the Mg-Air battery during circulation. The flow rate of the electrolyte coming from the side Mg-Air battery cell through circulation is $\mathrm{Q} 1$, the amount of by-products generated by discharge is $\mathrm{Q}_{2}$, the amount of electrolyte flowing from the upper tank is Qin, and the amount of electrolyte discharged through the electrolyte circulation outlet is Qout. The ideal circulation state is given in equation (7).

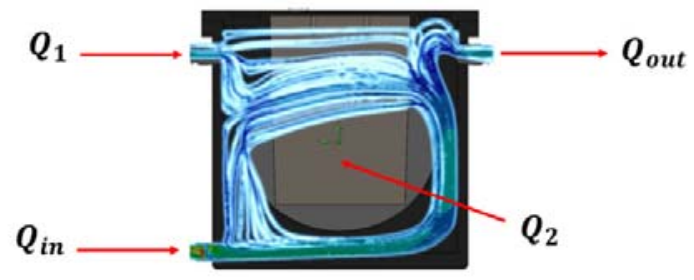

Figure 5. Electrolyte movement inside the Mg-Air Battery during circulation.

$$
\text { Steady State : } Q_{\text {in }}+Q_{1}+Q_{2}=Q_{\text {out }}
$$

The electrolyte outlets of each cells were connected through fittings, total circulation method was applied, which is a method in which 25 electrolytes located in one layer are circulated using a single tube. Thereafter, from 0 to $12 \mathrm{~A}, 30$ minutes were maintained per $0.1 \mathrm{~A}$ and discharged for a total of 60 hours.

As a result, the rate at wich by-products are generated is faster than the rate at which the electrolyte is circulated, and it was comfirmed that by-product was loaded in most Mg-Air battery.

Figure 6 is a picture of Mg-Air battery loaded with byproduct, and the corresponding circulation state of the battery can be expressed by equation (8) and (9).

$$
\begin{gathered}
\text { Non - Steady State : } Q_{\text {in }}+Q_{1}+Q_{2}>Q_{\text {out }} \\
\text { Collapsed }: Q_{\text {in }}+Q_{1}+Q_{2} \gg Q_{\text {out }}
\end{gathered}
$$
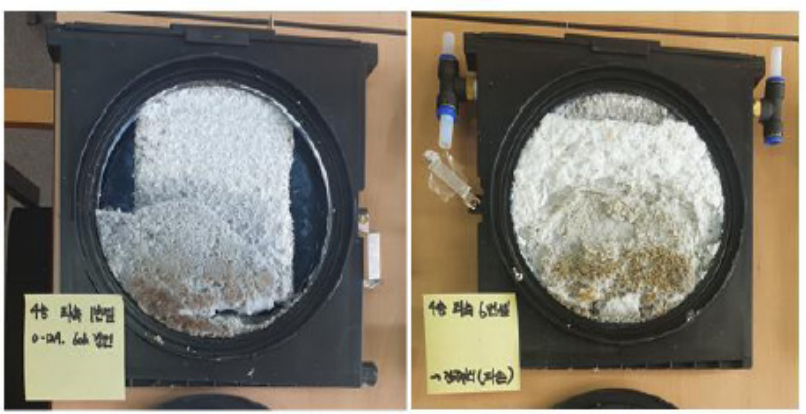

Figure 6. Total circulation type Mg-Air battery loaded with by-product. The left is the state of equation (8) and the right is the state of equation (9)
It was comfirmed that the total circulation method not efficient in removing by-products, in order to enhance the circulation effect, a circulation pipe was connected directly from each electrolyte outlet to the lower tank, and an individual circulation method was applied to allow circulation in each Mg-Air battery.

Discharge conditions were maintained for a total of 60 hours, maintaining 30 minutes per $0.1 \mathrm{~A}$, from 0 to $12 \mathrm{~A}$ in the same manner as the total circulation. As a result, it was confirmed that the by-product loading phenomenon was improved compared to the total circulation method.

Figure 7 is a picture of Mg-Air battery with an individual circulation method applied.

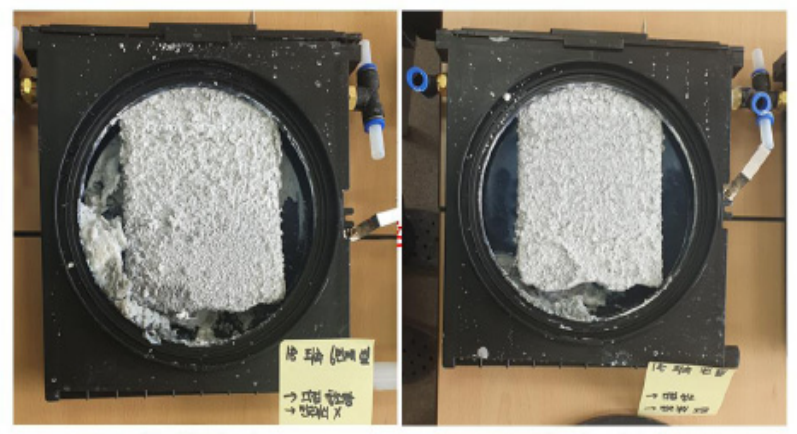

Figure 7. Individual circulation type Mg-Air battery loaded with by-product.

Figure 8 Shows the output when the Mg-Air battery rack is driven for 60hours through each circulation method. The total circulation method shows a higher output at a low discharge current of $1 \mathrm{~A} / \mathrm{Cell}$ or less, but it can be confirmed that the output of each circulation method is almost constant when more discharge current is applied.

Through this, it was confirmed that the individual circulation method has similar performance to the total circulation method in terms of output, but can have a better effect on the maintenance through the removal of by-products.

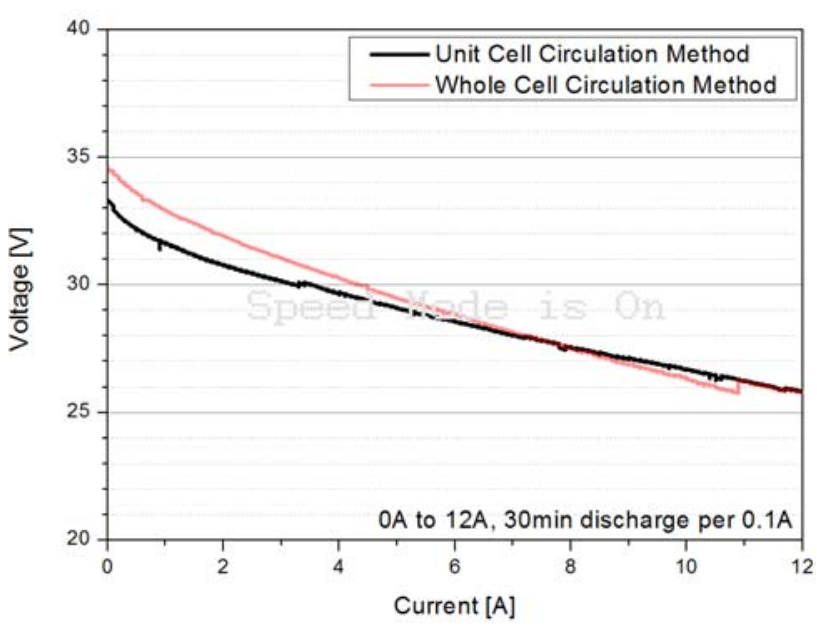

Figure 8. Output of Mg-Air battery rack according to circulation method 


\section{Conclusion}

Through the modelling of the discharge energy density, the efficiency of the discharge energy density of Mg-Air battery according to whether or not the electrolyte is circulated was determined.

In addition, in order to confirm the effect of removing by-products according to the circulation method, a largecapacity Mg-Air battery rack was actually constructed.

As a result, it was confirmed that the individual circulation method had better electrolyte removal effect than the entire circulation method. When an actual power facility was built using Mg-Air battery, it was confirmed that the energy efficiency of the Mg-air battery could be increased by $20 \%$ through the provision of an electrolyte circulation facility in terms of maintenance.

\section{Acknowledgments}

This research was supported by the Technology Innovation Program (20001088, Development of environment friendly personal emobility products and experiential sharing platform service design based on tourismlesport) funded By the Ministry of Trade, industry \& Energy (MI, Korea)

\section{References}

1. Y.H. Kim, Trans KIEE 61, 3, 134 139(2012)

2. B. worth, A. Perujo, and K. douglas, WP ST9Metal/Air Reprot, 1-19 (2002)

3. Richard, K et al, J. Engng. Ed. Vol. 18, 3, 379-388 (2002)

4. S.M. Faris et al, US patent $6,544,678 B 2,(2003)$

5. Z. H-Y, B. Pei and J.U dongwing, J. Environmental sciences supplement, s88-s91 (2009)

6. Y.H. Kim J. KIEEME, 23, 1002-1006 (2010)

7. A. Kaisheva, protable and emergency energy sourcefrom materials to systems, 16-22 (2005)

8. L. Chen, et al, Chin. Sci. Bull, 1936-1941 (2014)

9. S. Sathyanarayna and B.V.Ratnakumar, J. Power Sources, 10, 243-261 (1983)

10. B.V. Ratnakumar and S.Sathyanarayana, J. Power sources, 12, 39-51 (1984)

11. R. Roffia, V.conicalini, and C. Pardisi, J. Chem. Educ. 65, 3(1988)

12. J.H Kim, S.U, Uum, S. E. Moon, M.S Youn, J.Y. Kim, J.S. Park, and J.H. Park, J.KIEE. 17, 4 (2004)

13. D.A.J. Rand, R. Woods, and R.M. Dell, Batteries for Electric Vechicles (John Wiley \& Sons Inc, 1998)

14. K. F. Blurton, and A. F. Sammells, J. Power source, 4 (1979)

15. A. Perujo, and K. Douglas, Storage technology report WPST 9 (2002)

16. Y.H. Kim, Trans KIEE 59, 9(2010) 